\title{
Mitigation of the environmental risks resulting from diesel vehicle operation at the mining industry enterprises
}

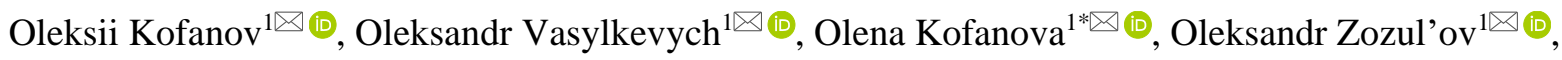

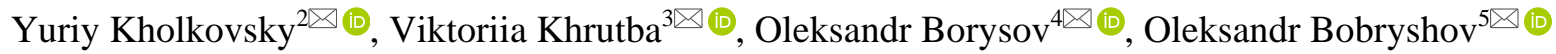 \\ ${ }^{I}$ National Technical University of Ukraine "Igor Sikorsky Kyiv Polytechnic Institute”, Kyiv, 03056, Ukraine \\ ${ }^{2}$ National Aviation University, Kyiv, 03058, Ukraine \\ ${ }^{3}$ National Transport University, Kyiv, 01010, Ukraine \\ ${ }^{4}$ Desna-S-LTD LLC, Kyiv, 02218, Ukraine \\ ${ }^{5}$ Dnipro University of Technology, Dnipro, 49005, Ukraine \\ *Corresponding author: e-mail alexina555@gmail.com, tel. +380442049917
}

\begin{abstract}
Purpose is to predict potentially hazardous effects of diesel vehicles of mining enterprises on the environment and to minimize the environmental risks caused by these impacts by modifying motor fuels with special additives.

Methods. Method of mathematical modeling, implemented within the MathCAD environment, was used for assessment of the increase of environmental load on the roadside territories and human health caused by emissions of pollutants from exhaust gases of heavy diesel vehicles (HDV) of mining enterprises. The data, concerning potential emissions of the most hazardous pollutants from the exhaust gases of HDVs, has been generalized both by own field observations and by the analysis of scientific literary sources. The load on the environment by the analyzed pollutants has been corrected taking into consideration the share of heavy diesel vehicles engaged in cargo carriages by means of pendular routes of mining enterprises.
\end{abstract}

Findings. Increased level of the environmental risk, resulted from operation of heavy diesel vehicles and other types of special-purpose diesel machines, has been identified. It has been proposed to apply a method of physical and chemical control of the motor fuel by adding multifunctional fuel composition (i.e. additive) containing both surface-active and antioxidant complexes. It has been determined that the use of the developed additive decreases substantially the load on the environment, in particular, on the roadway - by $26-29 \%$ for nitrogen oxides and by $39-41 \%$ for particulate matter (PM). The abovementioned mitigates environmental risks as well as the impact of heavy diesel vehicles on the human health. The substantial reduction of the distances, within which safe concentration levels of the analyzed pollutants can be observed, has been achieved.

Originality. It has been identified that the diesel fuel modification by the developed additive makes it possible to solve a problem of local and diffuse pollution of a roadside space resulted from HDV emissions. It has been proved that the use of the fuel composition decreases toxic level of exhaust gases of diesel motors and reduces fuel consumption while improving the fuel burning conditions as well as air-fuel mixture forming.

Practical implications. The obtained results may be applied to improve ecological safety level of the roadside territories and to minimize the ecological risks resulted from HDVs of mining enterprises for the environment and human health.

Keywords: diesel vehicles, mining industry, environmental risk, additives, exhaust gases, biodiesel

\section{Introduction}

Currently, the world countries including Ukraine more and more often face the necessity to mitigate ecological risks by the development of innovative advanced technologies of the environment protection, methods for environment conditions evaluation and by providing ecological safety of the industrial environments. Hence, development and implementation of the efficient measures improving environmental friendliness of industrial objects of mining industry (MI), their machinery fleet etc. first need renovation of techniques evaluating and controlling environmental risks and impacts as well as substantial measures to minimize them, to remodel awareness of the enterprise authorities etc.

Ukraine is among the countries with the developed mining and processing industries. Thus, traffic arrangement of heavy vehicles (HDV) of mining enterprises and minimization of its ecological impact on the environment become very important issues. Recently, many national and foreign researchers have been engaged in the analysis of hazardous impact of vehicles on the roadside territories and on the human health [1]-[3].

Impact of exhaust gases emissions, being formed in the process of internal combustion engines operation, has been 
analyzed in [4], [5]; advantages and disadvantages of the alternative fuel use (in particular, of a plant origin) have been analyzed in [6]-[9]. There are important researches concerning the problems of greenhouse gas emissions and their effect on the global climate changes [10]-[15].

Papers [16]-[20] have developed scientific foundations of the modification of composition of motor fuels by differing in characteristics additives and agents as well as of the decrease in load on the environment by operating diesel vehicles. Papers [21], [22] should also be mentioned since they analyze heavy diesel motor impact on the environment and on the roadside territories, and impact of vehicles and mining enterprise special-purpose machines on the environment and human health [23]-[25].

Among other things, paper [25] analyzes emissions of such nitrogen compounds as $\mathrm{NO}_{x}, \mathrm{NO}, \mathrm{NO}_{2}, \mathrm{NH}_{3}$, and $\mathrm{N}_{2} \mathrm{O}$ as well as fine solid dust particles (also known as PM) resulting from the operation of heavy diesel motor energized by diesel fuel (DF) and its mixture with soya biodiesel (20\% of biodiesel). The authors mention that the use of the mixture motor fuel helps to reduce drastically the pollution concentrations within exhaust gases of the engine even in comparison with low-sulfur DF. Special attention has been paid to the selective catalytic reduction system (SCR), which enabled almost $68 \%$ decrease in nitrogen oxide emissions and $93 \%$ decrease in emissions of nitrogen (II) oxide NO. However, due to the SCR system functioning, all fuel types, including mixture ones, increased emissions of ammoniac $\mathrm{NH}_{3}$, and nitrogen (I) oxide $\mathrm{N}_{2} \mathrm{O}$. The authors estimated a noncancerogenic risk of the motor operation as a low one. Nevertheless, they mentioned that the statement is relevant for the countries where environmental standards are not less than Euro-5.

Paper [26] analyzes the effect of ultra-low-sulfur DF replacement by the mixture motor fuel (B20, i.e. $20 \%$ of biodiesel), and on the soya biodiesel (B100) in terms of heavy diesel motor Cummins ISB operation with the use of diesel particulate filter (DPF). It has been determined that in comparison with a base fuel, the use of mixture motor fuel and biodiesel have helped to reduce drastically the emissions of the unburned volatile hydrocarbons and polyaromatic hydrocarbons - almost $40 \%$ of reduction for B20, and even more for B100. However, DF substitution for biodiesel did not effect benzene emissions; in turn, naphthalene emissions even increased for B100. To some extent, use of a mixture motor fuel decreased acrolein emissions; however, even DPF usage was not able to reduce the formaldehyde emissions.

Paper [23] analyzes the influence of the temperature in the motor chamber on the amount of particulate matter emissions. The analyzed trucks were equipped with a particulate filter (the first one) and a system controlling emissions of nitrogen oxides SCR (the second one). The studies involved both ultra-low-sulfur DF and a mixture fuel B20 in terms of different loads and operation cycles. Decrease in soot particle emission was observed with the decreasing temperature and with the transiting of the HDV to a mixture fuel B20.

Interest is provoked by the papers, which concern the modeling of processes of dispersion of pollutants within the ground-level roadside space as well as developing of methods to evaluate atmospheric air pollution by exhaust gases of vehicles [27]-[33]. However, despite the listed achievements, evaluation of environmental risks from HDVs, especially in the context of operation of industrial objects of MI, still remains the important problem today. Its solution is the scientific foundation in the process of elaboration of measures to provide environmental safety of both roadside and production areas, population health protection etc.

Generally, Ukrainian mining and processing enterprises are concentrated within the small areas; very often, within the so-called industrial-urban agglomeration or in its immediate vicinity. The abovementioned create extra environmental problems for the roadside territories, their eco-systems, population etc. Taking into consideration the fact that the freight traffic activity in the context of MI is a significant share of the total transportation, the problem to minimize emission volumes of internal combustion engines and to reduce their toxicity is one of the most topical and important problems from the viewpoint of the national environmental security, ensuring its sustainable development.

Effect of emissions by internal combustion engines (which concerns, in particular, cargo vehicles) not only deteriorates significantly quality of roadside soils, surface water and ground water, atmospheric air etc. As a result, natural eco-systems are injured and hazard is constituted for the health of people who live in the neighbourhood of the roads and those who are their users. In this context, the degradation often concerns recreational territories, water bodies, and spontaneous resting places. Moreover, emission of greenhouse gases and dust produced by heavy machinery of MI is a serious problem as well. Hence, it is extremely important to develop scientific foundation for the evaluation of environmental risks resulting from the diesel vehicle operation with modeling of geoecological conditions of roads and nearby territories as well as implementation of the efficient measures to minimize diesel impact on the environment components and human health.

The research objective is to predict potentially hazardous effects of diesel vehicles of mining enterprises on the environment and to minimize the environmental risks caused by these impacts by modifying motor fuels with special additives.

\section{Methods}

Each stage of the production and raw material preparation needs the developed transportation network. For instance, raw material delivery from an open pit (mine) to a plant or warehouse is meant or the product delivery from a plant to a warehouse or to a customer; or transportation of various cargos, personnel etc. As a rule, mining enterprises apply the combined transport systems where diesel facilities have a leading role. Among other things, in the context of open-pit mining, diesel dump trucks transport up to $70-80 \%$ of rock mass; diesel specific machinery is applied in the process of underground mining too.

In turn, environmental risk is connected with the potential environmental damage, health risks, decrease in human wellbeing etc. Actually, a number of risks are identified which can arise under certain conditions and cause emergency situations within the analyzed territories; moreover, their potential aftereffects per certain period are evaluated [34]. Scientific sources also use such a notion as "risk degree" demonstrating, in the eyes of scientists, its qualitative nature more visually [35].

Hence, taking into consideration possibility of qualitative evaluation, we can identify environmental risk as a ratio between a value of potential damage by some ecological factor, acting during certain period of time, and the normalized intensity value of the factor [35], [36]. Thus, to evaluate 
the environmental risks from the viewpoint of diesel vehicles, operating at MI objects and carrying cargos by suburban roads, the method of mathematical modeling within the MathCAD environment was applied. During the development of the concentration fields of the main pollutants of diesel vehicles (i.e. nitrogen oxides and PM), the model of a torch approximation according to the method of M.Ye. Berlyand in the interpretation of V.O. Kholodnov and associates was used [37], [38].

The model enables solving a semi-empirical equation of a turbulent diffusion for a linear source of pollution (i.e. a road section) as the set of point emission sources on the basis of the superposition principle of concentration fields of a certain pollutant. Papers [37]-[39] give rather detailed description concerning specific features of the software usage and determination of diffusion coefficients of the certain pollutants. Results of the potential vehicle load on the road as well as on the roadside space have been averaged in terms of field observations (both own ones and those taken from scientific sources) involving a share of diesel trucks and buses [40]. Calculation results of ground concentrations of the pollutants were provided in terms of a multiplicity exceeding their maximum permissible single concentration (MPC).

\section{Results and discussion}

Cargo transportation of mining enterprises is followed by the emissions of such pollutants as carbon oxide, nitrogen oxide, sulfur oxide, the unburnt hydrocarbons (including cancerogenic ones), soot etc. from HDV engines, as well as other emissions such as surface road destruction; deterioration of tires and brake pads; blowout of a material because of other reasons etc. That is why the processes of organizational management of truck fleets of mining enterprises need special attention since the transportation system should provide not only the efficient and timely delivery of cargos, personnel etc. but also minimize DF consumption and emissions of pollutants including greenhouse gases.

Emission volumes of pollutants depend upon the type of a vehicle, its carrying capacity, technical conditions, duration of its performance, motor fuel type, physical and chemical characteristics of the material being transported as well as condition of the road surface and its type; meteorological and climatic conditions; orography of the territory and many other factors. In addition to trucks, mining enterprises are equipped with excavators, dozers, and other machines and mechanisms.

It is known that excessive emissions of soot and PM are among the key disadvantages of diesel vehicles. Moreover, the emissions are hazardous for the environment as well as for human health and animals since they can absorb other pollutants at own surface including cancerogenic and mutagenic hydrocarbons. Aerosols with solid inclusions of 1-2 $\mu \mathrm{m}$ and less than $0.3-0.4 \mu \mathrm{m}$ are the most dangerous ones since they can penetrate into lungs deeply remaining there for a long time.

To identify the emission volumes of pollutants from vehicle motors, energized by DF, the basic indices of their performance were analyzed. As an example a heavy diesel vehicle, the KrAZ-257B1 operating within a pendulum route of a modeling mining enterprise was considered. Its cargo can be represented by lignite, coke etc. Such vehicles still operate at different objects of mining industry worldwide; the abovementioned especially concerns former USSR countries.
Table 1 demonstrates specification of the KrAZ-257B1 vehicle (according to the data of its manufacturer). Its average running exhaust emissions (i.e. volumes of pollutant emissions from the exhaust system of the vehicle per travel unit, $\mathrm{g} / \mathrm{km}$ ) without pollutant emissions at idling are as follows: $6.1-7.4 \mathrm{~g} / \mathrm{km}$ in terms of carbon (II) oxide $\mathrm{CO}$; $1.0-1.2 \mathrm{~g} / \mathrm{km}$ in terms of the unburnt carbohydrates $\mathrm{C}_{x} \mathrm{H}_{y}$; $4.0 \mathrm{~g} / \mathrm{km}$ in terms of nitrogen oxides $\mathrm{NO}_{x} ; 0.30-0.40 \mathrm{~g} / \mathrm{km}$ in terms of soot C; and $0.54-0.67 \mathrm{~g} / \mathrm{km}$ in terms of sulfur (IV) oxide $\mathrm{SO}_{2}$ depending upon a season [41].

Table 1. Specifications of a KrAZ-257B1 vehicle

\begin{tabular}{lc}
\hline \multicolumn{1}{c}{ Indices } & Values \\
\hline Capacity, $\mathrm{t}$ & 12 \\
Motor & YaMZ-238 \\
Volume, $\mathrm{cm}^{3}$ & 14866 \\
Maximum motor power & $176 \mathrm{~kW}$ at $2100 \mathrm{rpm}$ \\
Cylinders & 8 \\
Compression degree & 16.5 \\
Fuel consumption & $381 / 100 \mathrm{~km}$ \\
Tank capacity, 1 & $2 \times 165$ \\
\hline
\end{tabular}

The analysis has shown that DP consumption for one KrAZ-257B1 truck with $12 \mathrm{t}$ capacity is almost 9-10 1 per $15-25 \mathrm{~km}$ of pendulum travel (taking into consideration DP consumption at idling). According to information provided by [41], extra emission of $\mathrm{CO}$ is about $185 \mathrm{~g} ; \mathrm{C}_{x} \mathrm{H}_{y}-\sim 30 \mathrm{~g}$; $\mathrm{NO}_{x}-\sim 100 \mathrm{~g}$, soot $-\sim 100 \mathrm{~g}$; and $\mathrm{SO}_{2}-\sim 16.8 \mathrm{~g}$ (the calculations were performed for a warm season and $25 \mathrm{~km}$ route length). However, evaluation of the diesel emission impact on the environment should also take into account the fact that the majority of mining enterprises use diesel vehicles for collecting and distributing routes (in particular by buses).

Figures $1 \mathrm{a}, \mathrm{b}$ and $2 \mathrm{a}$ show the concentration fields of the extremely hazardous emission components of diesel vehicles - nitrogen oxides (in terms of $\mathrm{NO}_{2}$ ) and particulate matter - for $5 \mathrm{~km}$ section of a suburban road extending tentatively from west to east within a two-meter ground air layer without taking into account additional load from diesel vehicles of the modeling mining enterprise. Blue isoline stands for the concentration of a particular pollutant being equal to its maximum permissible single concentration; maximum multiplicity of the maximum permissible single concentration excess of the certain pollutant is indicated in the central part of the road.

Involving the listed above evaluation data, concerning the increased pollutant emissions in the context of heavy diesel vehicle operation [41], Figures $2 b$ and $3 a$, b show concentration fields of the pollutants within the analyzed highway section in terms of similar meteorological conditions. As it can be seen, multiplicity of the maximum permissible single concentration excess of nitrogen oxides increases from 34.6 to $46.7 \mathrm{MPC}$ (i.e. 1.35 times increase can be observed at the north wind) and from 42.5 to $55.8 \mathrm{MPC}$ (i.e. 1.31 times increase at the south-east wind). Meanwhile, the distance, still demonstrating a dangerous pollutant concentration, experience its average $6.8 \%$ increase in terms of the north wind and $21.1 \%$ increase in terms of the south-east wind.

As for the particulate matter, the multiplicity of maximum permissible single concentration exceeding in terms of the mining enterprise HDVs operation will experience its 1.32 times increase at the north wind and 1.31 times increase at the south-east wind. 
(a)

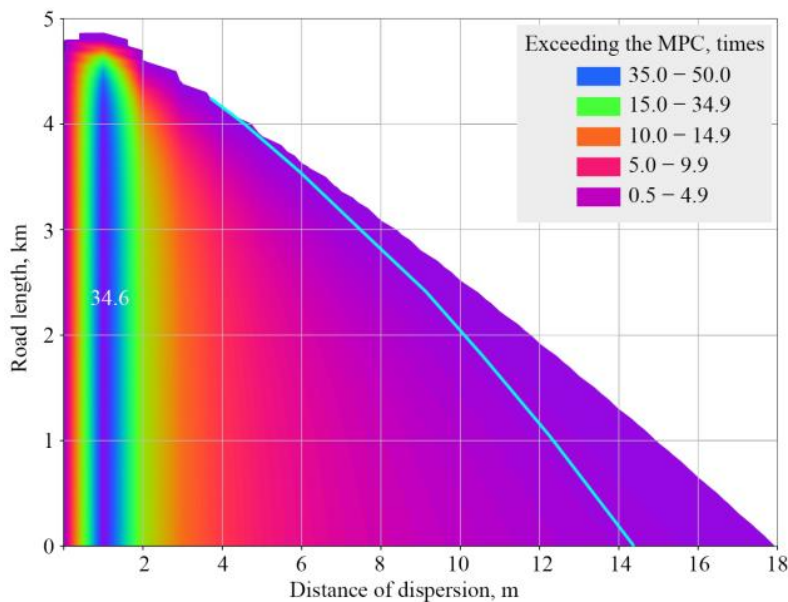

(b)

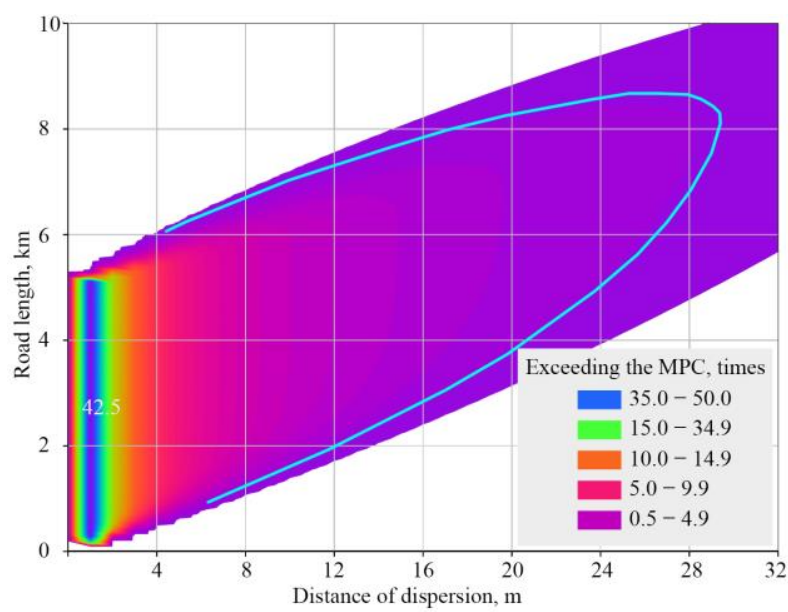

Figure 1. Concentration fields of nitrogen oxides (in terms of $\mathrm{NO}_{2}$ ) within the highway section: (a) at north wind; (b) at south-east wind (average wind speed is $5 \mathrm{~m} / \mathrm{s}$ ) without taking into account additional load by heavy diesel vehicles of a mining enterprise

At the same time, the distance, still demonstrating dangerous concentrations of the pollutant, shows average $45.8 \%$ increase in terms of the north wind and $28.6 \%$ increase in terms of the south-east wind. As it can be seen, the main share of PM deposit right within the highway increasing environmental risks, first of all, for the road users - drivers, bicyclers etc.

So, the increased emissions of pollutants from exhaust gases of diesel trucks result in the worsening of geoecological situation both within the territories nearby the highway, and within the road itself factoring into the deteriorated quality of atmospheric air, soils, ground water, surface water etc.

Taking into consideration the fact that generally suburban highways are located near settlements (often along them), crossing water bodies, farmlands, and recreation areas, the hazardous impact of diesel vehicles of MI objects causes additional ecological risks for the environment components, health of all road users (i.e., drivers, bicyclers, passengers of route taxis and suburban buses), and for residents of the settlements. (a)

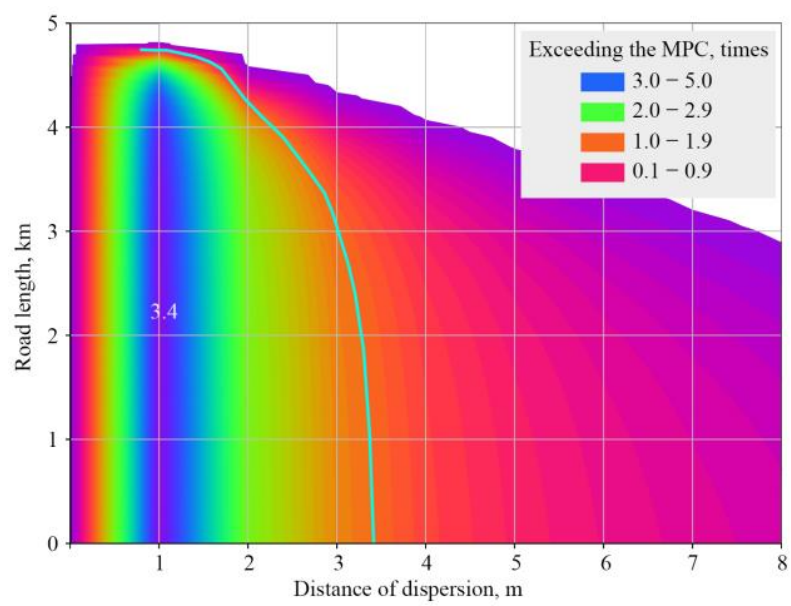

(b)

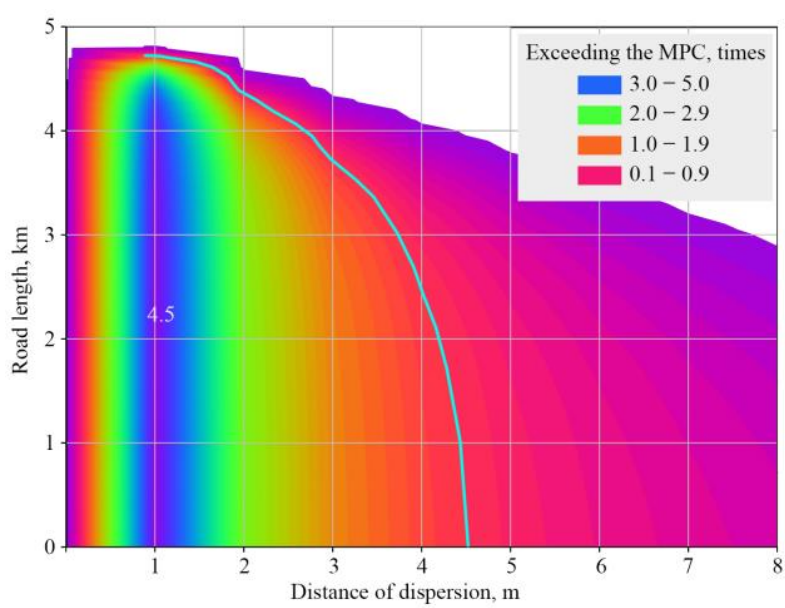

Figure 2. Concentration fields of particulate matter within the analyzed highway section in terms of the north wind which average speed is $5 \mathrm{~m} / \mathrm{s}$ : (a) without taking into account additional load by heavy diesel vehicles of a mining enterprise; (b) taking into consideration the additional load by heavy diesel vehicles

This is manifested mainly as for the ground space pollution by extremely hazardous nitrogen oxides when maximum permissible single concentration exceeding is more than 50 times; moreover, the pollutants can disperse over large distances producing secondary geochemical anomalies as well as local areas of extra contamination.

In addition to heavy vehicles, mining enterprises also use special-purpose facilities (i.e. excavators, dozers, motor graders, loaders etc.) with diesel, electro-diesel, and dieselhydraulic power equipment. It is quite understood that any enterprise having import and contemporary specific fleet with energy-saving power equipment meeting the requirements of EU Stage IV / US EPA Tier 4 Final Standard and higher, will be able to minimize both extra load on its working area air and employee health. However, not only Ukraine but also many world countries are still applying special-purpose facilities equipped with motors of environmental class Tier 2. In such a case, the environmental risks, resulting from the production activities of an enterprise, are complemented by a harmful effect of toxic exhaust gases emissions of the diesel machinery. 
(a)

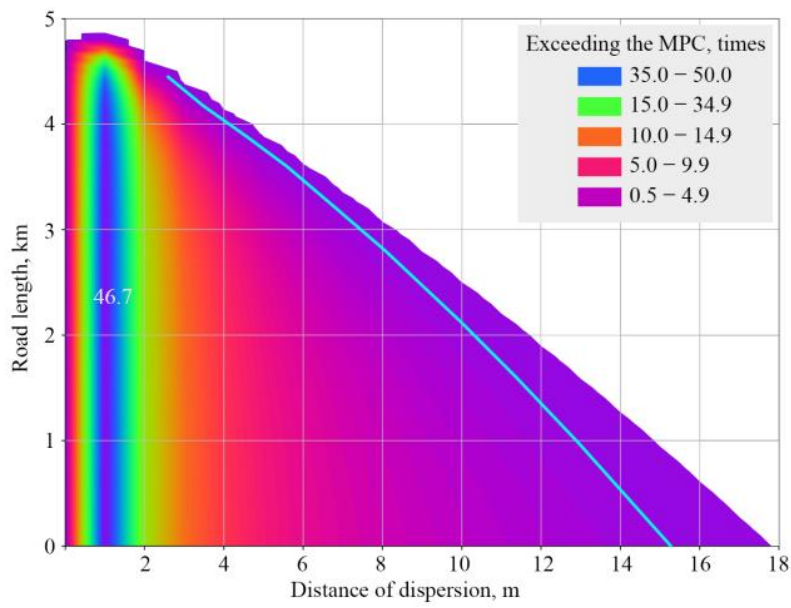

(b)

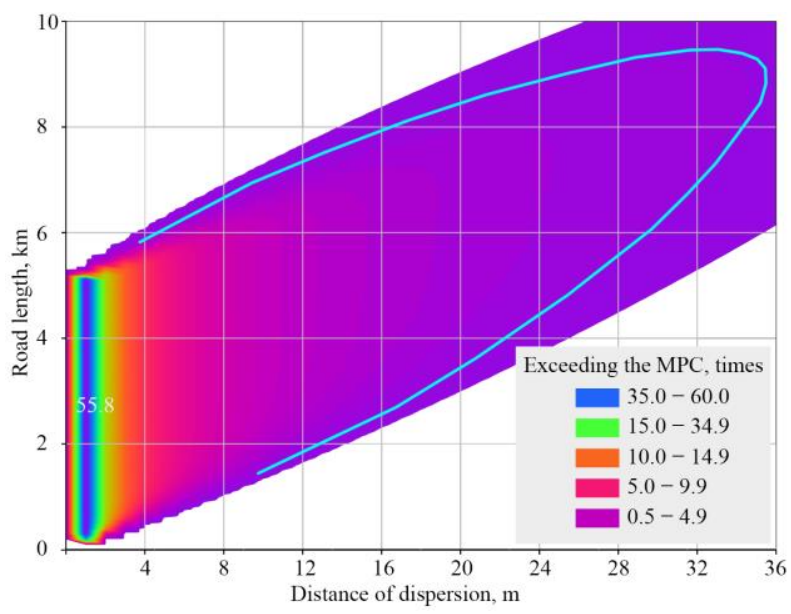

Figure 3. Concentration fields of nitrogen oxides (in terms of $\mathrm{NO}_{2}$ ) within the highway section: (a) in terms of the north wind; (b) in terms of the south-east wind (average wind speed is $5 \mathrm{~m} / \mathrm{s}$ ) taking into consideration additional load by heavy diesel vehicles of a mining enterprise

It is known that eco-economic and operational characteristics of vehicles depend heavily upon motor fuel quality and, among other things, upon its fractional composition, physical and chemical properties etc. [42]. Change of these properties by adding specific substances (i.e. additives or agents) to the fuels is named as a method of physical and chemical control (MPCC) of fuel characteristics. Hence, the result-oriented changes in a fuel composition (combined with its high quality, efficient systems of the exhaust gases purification from pollutants, emission control etc.) make it possible to implement a number of environmental measures to improve geoecological situation of a mining enterprise.

Motor fuel additives vary in their chemical nature and composition; they give the fuel new, improved qualities. As a rule, their percentage is up to $20-30 \%$, and they are added during production, filling, or vehicle operation. Additives also improve fuel characteristics; however, their share is from 3-5 to $50 \%$. In this context, additives and agents should not deteriorate the fuel quality or harm fuel facilities of the vehicle.

A number of various additives, agents, additive packages, fuel compositions etc. are proposed worldwide. They effect certain characteristics of a fuel or a vehicle. For instance, there are depressor additives (or antigel ones) decreasing temperature of fuel solidification as well as temperature of its boundary filtering; anti-corrosion additives (those reducing corrosion aggression of the fuel); additives to increase either cetane or octane ratio; anti-exhaust additives (those reducing emissions of PM while decreasing the engine smokiness but have almost no effect on the emissions of other pollutants); anti-burn and detergent-dispersant additives (those slowing down a process of engine sludge formation; making detergent effect; adding anti-ice and anti-corrosion properties to the motor fuel; favouring the conditions of mixture formation and fuel combustion); anti-oxidants (those improving thermooxidation resistance and preventing from resin- and emulsion formation); metal deactivators (those fixing metal promoters of oxidation of hydrocarbons (i.e., cuprum, ferrum, and others) in the inactive complexes); ignition promoters (those improving fuel ignition); biocidal additives (those slowing down generation of various bacteria within the motor fuels) etc.

Nevertheless, so-called additive packages become the most popular ones. They are fuel compositions of multifunctional action enhancing the effect of each of the components. To achieve a positive result, they are generally added to a motor fuel at a rate of 0.01-0.5\% of mass. Even addition of aquatic solution or alcoholic solution of chemically active substances (i.e. combustion activator) to the motor fuel is quite efficient. Addition of hydrogen, improving spraying and mixture formation, is another technique to effect fuel characteristics. Motor fuel properties may be varied while adding different amounts of biofuels (i.e. biomethanol, bioethanol, biobutanol, biodiesel etc.).

Hence, to mitigate pollution of the roadside territories of mining industry objects and to improve their environmental safety, the use of the MPCC was proposed. To improve ecological and economic properties of heavy diesel vehicles and other diesel machinery used by mining enterprises, it was proposed to add oxygenates (in particular, those of a plant origin) to motor fuel as well as complex-action additive package.

It was determined that addition of biodiesel in the concentration of $0.5-5 \%$ vol. to the traditional DF has almost no effect on a cetane number while improving substantially physical and chemical, as well as operational characteristics of the fuel, enhancing its lubricant and frictional properties. The abovementioned is extremely important for the countries where motors are energized by ultra-low-sulfur fuel with no more than 15 parts-per-million (ppm) sulfur content.

In this regard, a multifunctional fuel composition (FC) of the "additive-solvent-DF" type has been developed by the authors. According to the proposed authors' technique for the FC preparation, biodiesel is applied as a solvent and friction modificator. The biodiesel has been obtained from foodindustry waste and wood-working waste. However, the composition can be prepared with traditional DF or 2-propanol. The additive was proportioned in such a way that its mixture with DF would correspond to the current Standard requirements and favour the improvement of ecological and economic characteristics of the engine with no deterioration of its operational characteristics. Specific attention has been paid to environmental safety of the ingredients, their compatibility, concentration balance, and to the potential synergistic effects [43].

The developed FC is of detergent-dispersing action as well as of antioxidant and anticorrosion one owing to the availability of two complexes - surface-active complex and antioxidant one. 
Surface-active complex of the FC is represented by oxyethylated alkylphenol, as well as by ester of sorbitol and fatty carboxylic acid (by sorbitan oleate or sorbitan palmitate being nonionic surfactants). Sorbitan oleate $\mathrm{C}_{24} \mathrm{H}_{44} \mathrm{O}_{6}$ and sorbitan palmitate $\mathrm{C}_{22} \mathrm{H}_{42} \mathrm{O}_{6}$ are lipophilic surfactants; their hydrophilic-lipophilic balance is 4.3 and 6.7 respectively. Owing to a hydrophobic radical, the surfactants can dissolve (or disperse) in fats, oils, and other hydrophobic solvents; polyoxyethylene groups, which length determines the hydrophilic properties, are hydrophilic units of molecules.

Antioxidant complex inhibits free-radical processes within the fuel identifying antioxidant action [43], [44]. Consequently, the additive acts on the conditions of the surface of fuel-air phase separation, reducing surface tension of the system and reducing pressure of the saturated steam of the liquid phase. Changes in the surface tension of the system is quite important to optimize processes of mixture formation and combustion since the surface system effects droplet fineness and motor fuel spraying as well as combustion torch length.

The additive is added to a motor fuel as $0.05-0.20 \%$ vol. Road tests have shown that to compare with the pollutant emissions resulting from operation of motors, energized by $\mathrm{DF}$, use of the $\mathrm{FC}$ in the mentioned quantities, results into $23-27 \%$ decrease in $\mathrm{CO}$ emissions; $8-10 \%$ decrease in nitrogen oxide emissions (in terms of $\mathrm{NO}_{2}$ ); and 26-27\% decrease in hydrocarbon emissions. In this context, index of exhaust gases smokiness experiences its $27-29 \%$ decrease; fuel consumption decreases by 4-9\% depending upon operation schedule of the facilities.

Figure $4 \mathrm{a}, \mathrm{b}$ demonstrates concentration fields of the analyzed pollutants, i.e. exhaust gases components of diesel vehicles, after hypothetic use of the developed fuel composition as an additive to DF (taking into consideration a share of trucks within the traffic of suburban highway). The modeling results of dispersion fields of the pollutants have shown that after such hypothetic use of the motor fuel modified by the developed additive, the lower levels the maximum permissible single concentration exceeding can be observed, including those within a road way (1.26 times decrease for nitrogen oxides and 1.41 times decrease for PM at the north wind). Safe pollutant concentrations can be achieved at shorter distances from the highway (13.8 $\mathrm{m}$ in comparison with $14.2 \mathrm{~m}$ for nitrogen oxides and $2.2 \mathrm{~m}$ in comparison with $3.5 \mathrm{~m}$ for PM).

In terms of the south-east wind, excess of maximum permissible single concentration of the impurities is 1.29 times for nitrogen oxides and 1.39 times for PM respectively. Safe concentrations of the impurities can be achieved at shorter distances from the road $(26.8 \mathrm{~m}$ in comparison with $34.5 \mathrm{~m}$ for nitrogen oxides and $2.3 \mathrm{~m}$ in comparison with $3.6 \mathrm{~m}$ for PM). Application of the discrete-interpolation approach proposed by Yu.R. Kholkovsky has helped to identify the possibility to specify the developed models of pollutant dispersion taking into consideration the territory orography, meteorological and climatic conditions, and geometry of certain sections of the road. Paper [39] describes the approach in more detail.

So, under the conditions of the increasing technogenic load on the biosphere components (i.e., atmospheric air, soils, surface water, ground water etc.), systematic control is essential as well as the development of efficient measures to mitigate the harmful impacts. Use of the MPCC makes it possible to mitigate environmental risks and improve the geoecological situation on the highways and roadside space by modification of the motor fuel. (a)

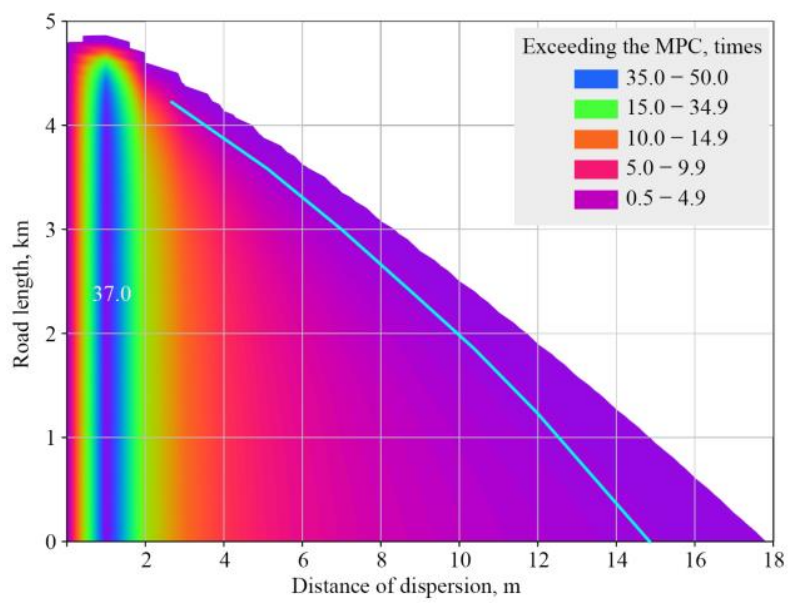

(b)

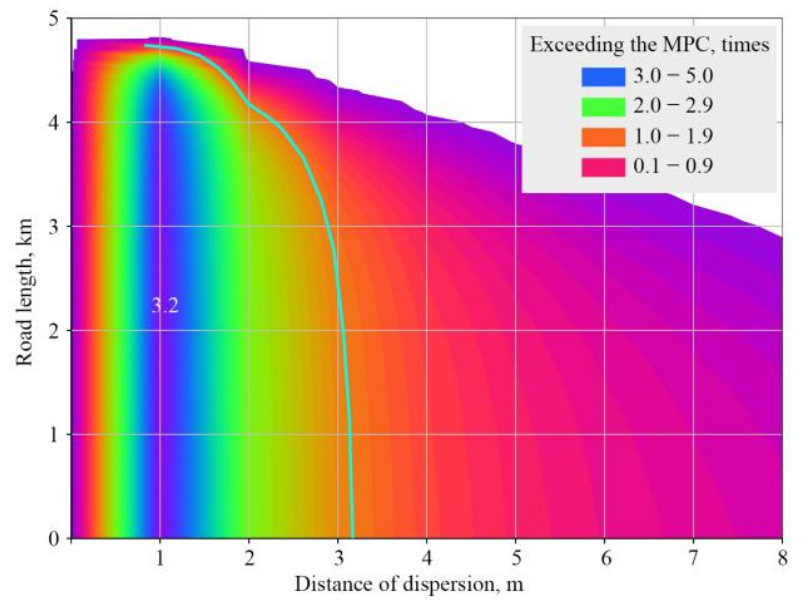

Figure 4. Concentration fields of: (a) nitrogen oxides (in terms of $\mathrm{NO}_{2}$ ); (b) particulate matter within the analyzed highway section taking into consideration hypothetic energizing of heavy diesel vehicles of a mining enterprise with the fuel modified by additive (the north wind with $5 \mathrm{~m} / \mathrm{s}$ average speed)

\section{Conclusions}

It has been identified that the roadside territories of MI objects as well as the territories in the neighbourhood of suburban highways are ecologically dangerous since they demonstrate substantial exceed in the maximum permissible concentration of pollutants partially conditioned by a pressure from heavy diesel vehicle operation.

It has also been determined that among a number of pollutants, released by diesel motors into the atmosphere, carbon oxides, nitrogen oxides, and sulfur oxides as well as particulate matter are the most toxic and hazardous ones.

It was proposed to use the MPCC of motor fuel characteristics with the help of specific fuel compositions containing surface-active and antioxidant complexes. The developed FC, adding to DF in the amount up to $0.20 \%$ vol., has almost no influence on a cetane number of the fuel; increases its density and kinematic viscosity within acceptable values. However, it decreases substantially surface tension of the fuel system. Because of the use of a biodiesel as a solvent, the additive improves tribological characteristics of low-sulfur DFs with no deterioration in their physical and chemical, as well as in the performance properties. 
By the method of mathematical modeling it was forecasted that DF modification with the help of the developed FC makes it possible to solve partially a problem of both local and dispersed pollution of the roadside space resulting from the emissions of heavy diesel vehicles. It has been determined that the additive helps to reduce motor fuel consumption and decreases exhaust gases toxicity. Consequently, environmental load on the road way experiences its $26-29 \%$ decrease in terms of nitrogen oxides and $39-41 \%$ decrease in terms of particulate matter. In this context, maximum shortening of a distance, within which a safe concentration level of the analyzed pollutants can be observed, is $22.32 \%$ for nitrogen oxides (in terms of the south-east wind) and $37.14 \%$ for particulate matter (in terms of the north wind).

\section{Acknowledgements}

The authors are grateful to Mykola Borysovych Stepanov, Senior Researcher of the Special Design Bureau "Shtorm" of the National Technical University of Ukraine "Igor Sikorsky Kyiv Polytechnic Institute", and Ivan Mykhailovych Vasylkevych, Candidate of Chemical Sciences, Senior Researcher, for their help during the research conduction, and for provision of scientific advisory support.

\section{References}

[1] Eastwood, P. (2007). Particulate emissions from vehicles. WileyProfessional Engineering Publishing Series. - Chichester, United Kingdom: John Wiley \& Sons Ltd. https://doi.org/10.1002/9780470986516

[2] Merkisz, J., Pielecha, J., \& Radzimirski, S. (2014). New trends in emission control in the European Union. London, United Kingdom: Springer Tracts on Transportation and Traffic. https://doi.org/10.1007/978-3-319$\underline{02705-0}$

[3] Voloshkina, O., Sipakov, R., Varavin, D., Anpilova, Y., Kryvomaz, T., \& Bereznitska, J. (2018). Pollution of atmospheric air above the city highways. USEFUL Online Journal, 2(4), 9-25. https://doi.org/10.32557/useful-2-4-2018-0002

[4] Blanco-Rodriguez, D.-I. D. (2014). Modelling and observation of exhaust gas concentrations for diesel engine control. Springer Theses. London, United Kingdom: Springer Publishing. https://doi.org/10.1007/978-3319-06737-7

[5] Pope, C.A., \& Dockery, D.W. (2006). Health effects of fine particulate air pollution: Lines that connect. Journal of the Air \& Waste Management Association, 56(6), 709-742. https://doi.org/10.1080/10473289.2006.10464485

[6] Knothe, G., Van Gerpen, J., \& Krahl, J. (2005). The biodiesel handbook. Champaign, Illinois, United States: AOCS Press. https://doi.org/10.1201/9781439822357

[7] Lorne, D., \& Chabrelie, M.-F. (2011). New biofuel production technologies: Overview of these expanding sectors and the challenges facing them. IFP Energies Nouvelles.

[8] Rajagopal, D., \& Zilberman, D. (2007). Environmental, economic and policy aspects of biofuels. Foundations and Trends $\AA$ in Microeconomics, 4(5), 353-468. https://doi.org/10.1561/0700000029

[9] Zhu, H., Wu, Z., Chen, Y., Zhang, P., Duan, S., Liu, X., \& Mao, Z. (2006). Preparation of biodiesel catalyzed by solid super base of calcium oxide and its refining process. Chinese Journal of Catalysis, 27(5), 391-396. https://doi.org/10.1016/s1872-2067(06)60024-7

[10] Baklanov, A., Molina, L.T., \& Gauss, M. (2016). Megacities, air quality and climate. Atmospheric Environment, (126), 235-249. https://doi.org/10.1016/j.atmosenv.2015.11.059

[11] Cape, J.N., Tang, Y.S., Van Dijk, N., Love, L., Sutton, M.A., \& Palmer, S.C.F. (2004). Concentrations of ammonia and nitrogen dioxide at roadside verges, and their contribution to nitrogen deposition. Environmental Pollution, 132(3), 469-478. https://doi.org/10.1016/j.envpol.2004.05.009

[12] Folberth, G.A., Butler, T.M., Collins, W.J., \& Rumbold, S.T. (2015). Megacities and climate change - A brief overview. Environmental Pollution, (203), 235-242. https://doi.org/10.1016/j.envpol.2014.09.004

[13] Marlier, M.E., Jina, A.S., Kinney, P.L., \& DeFries, R.S. (2016). Extreme air pollution in global megacities. Current Climate Change Reports, 2(1), 15-27. https://doi.org/10.1007/s40641-016-0032-Z
[14] Peel, J.L., Haeuber, R., Garcia, V., Russell, A.G., \& Neas, L. (2012). Impact of nitrogen and climate change interactions on ambient air pollution and human health. Biogeochemistry, 114(1-3), 121-134. https://doi.org/10.1007/s10533-012-9782-4

[15] Robinson, M.A., Olson, M.R., Liu, Z.G., \& Schauer, J.J. (2015). The effects of emission control strategies on light-absorbing carbon emissions from a modern heavy-duty diesel engine. Journal of the Air \& Waste Management Association, 65(6), 759-766. https://doi.org/10.1080/10962247.2015.1005850

[16] Patrakhal'tsev, N.N. (2010). Regulirovanie DVS metodom izmeneniya fiziko-khimicheskikh svoystv motornogo topliva. Transport na Al'ternativnom Toplive, 3(15), 26-32.

[17] Agarwal, A.K., \& Das, L.M. (2000). Biodiesel development and characterization for use as a fuel in compression ignition engines. Journal of Engineering for Gas Turbines and Power, 123(2), 440-447. https://doi.org/10.1115/1.1364522

[18] Bakeas, E., Karavalakis, G., \& Stournas, S. (2011). Biodiesel emissions profile in modern diesel vehicles. Part 1: Effect of biodiesel origin on the criteria emissions. Science of The Total Environment, 409(9), 1670-1676. https://doi.org/10.1016/j.scitotenv.2011.01.024

[19] Knothe, G. (2005). Dependence of biodiesel fuel properties on the structure of fatty acid alkyl esters. Fuel Processing Technology, 86(10), 1059-1070. https://doi.org/10.1016/j.fuproc.2004.11.002

[20] Wcisło, G. (2013). Determination of the impact of FAME biocomponent on the fraction composition of diesel engine fuels. Combustion Engines, 154(3), 1098-1103.

[21] Jurić, V., \& Županović, D. (1970). Ecological impacts of diesel engine emissions. PROMET - Traffic \& Transportation, 24(2), 151-160. https://doi.org/10.7307/ptt.v24i2.287

[22] Reşitoğlu, İ.A., Altinişik, K., \& Keskin, A. (2014). The pollutant emissions from diesel-engine vehicles and exhaust aftertreatment systems. Clean Technologies and Environmental Policy, 17(1), 15-27. https://doi.org/10.1007/s10098-014-0793-9

[23] Book, E.K., Snow, R., Long, T., Fang, T., \& Baldauf, R. (2014). Temperature effects on particulate emissions from DPF-equipped diesel trucks operating on conventional and biodiesel fuels. Journal of the Air \& Waste Management Association, 65(6), 751-758. https://doi.org/10.1080/10962247.2014.984817

[24] Mueller, C.J., Boehman, A.L., \& Martin, G.C. (2009). An experimental investigation of the origin of increased $\mathrm{NO}_{\mathrm{x}}$ emissions when fueling a heavy-duty compression-ignition engine with soy biodiesel. SAE International Journal of Fuels and Lubricants, 2(1), 789-816. https://doi.org/10.4271/2009-01-1792

[25] Tadano, Y.S., Borillo, G.C., Godoi, A.F.L., Cichon, A., Silva, T.O.B., Valebona, F.B., \& Godoi, R.H.M. (2014). Gaseous emissions from a heavy-duty engine equipped with SCR aftertreatment system and fuelled with diesel and biodiesel: Assessment of pollutant dispersion and health risk. Science of The Total Environment, (500-501), 64-71. https://doi.org/10.1016/j.scitotenv.2014.08.100

[26] Ratcliff, M.A., Dane, A.J., Williams, A., Ireland, J., Luecke, J., McCormick, R.L., \& Voorhees, K.J. (2010). Diesel particle filter and fuel effects on heavy-duty diesel engine emissions. Environmental Science \& Technology, 44(21), 8343-8349. https://doi.org/10.1021/es1008032

[27] Taseiko, O.V., Mikhailuta, S.V., Pitt, A., Lezhenin, A.A., \& Zakharov, Y.V. (2009). Air pollution dispersion within urban street canyons. Atmospheric Environment, 43(2), 245-252. https://doi.org/10.1016/i.atmosenv.2008.09.076

[28] Berkowicz, R. (2000). A simple model for urban background pollution. Urban Air Quality: Measurement, Modelling and Management, 259-267. https://doi.org/10.1007/978-94-010-0932-4_28

[29] Dorokhov, O., Kharitonenko, G., \& Dorokhova, L. (2014). Methods and models of atmospheric air condition's assessment. Montenegrin Journal of Ecology, 1(1), 47-52.

[30] Trofymchuk, O., Kreta, D., Myrontsov, M., Okhariev, V., Shumeiko, V., \& Zagorodnia, S. (2015). Information technology in environmental monitoring for territorial system ecological assessment. Journal of Environmental Science and Engineering A, 4(2). https://doi.org/10.17265/21625298/2015.02.003

[31] Kesarkar, A.P., Dalvi, M., Kaginalkar, A., \& Ojha, A. (2007). Coupling of the weather research and forecasting model with AERMOD for pollutant dispersion modeling. A case study for PM10 dispersion over Pune, India. Atmospheric Environment, 41(9), 1976-1988. https://doi.org/10.1016/j.atmosenv.2006.10.042

[32] Wang, G., van den Bosch, F.H.M., \& Kuffer, M. (2008). Modelling urban traffic air pollution dispersion. Proceedings of the XXI Congress. Silk Road for Information from Imagery. The International Society for Photogrammetry and Remote Sensing, VIII(2), 153-158. 
[33] Zhu, S., Tey, L., \& Ferreira, L. (2015). Genetic algorithm based microscale vehicle emissions modelling. Mathematical Problems in Engineering, 1-9. https://doi.org/10.1155/2015/178490

[34] US Environmental Protection Agency. (1989). Risk Assessment methodology, environmental impact statement for NESHAPS radionuclides. US EPA 520/1-89-005

[35] Zabulonov, Yu.L., Khmil, H.A. (2009). Modeliuvannia otsinok ryzykiv nadzvychainykh sytuatsii tekhnohennoho ta pryrodnoho kharakteru. Modeliuvannia ta Informatsiini Tekhnolohii, (51), 81-85.

[36] Poberezhna, L.Ya. (2015). Kompleksna otsinka ekolohichnykh ryzykiv terytorii, prylehlykh do raionu rozrobky Kalush-Holynskoho rodovyshcha kaliinykh solei. Visnyk Kremenchutskoho Natsionalnoho Universytetu im. Mykhaila Ostrohradskoho, 3(115), 1(92), 150-156.

[37] Berlyand, M.E. (1975). Sovremennye problemy atmosfernoy diffuzii $i$ zagryazneniya atmosfery. Leningrad, Rossiya: Gidrometeoizdat

[38] Kholodnov, V.A., Reshetilovskiy, V.P., Lebedeva, M.Yu., \& Borovinskaya, E.S. (2007). Sistemnyy analiz i prinyatie resheniy. Komp'yuternoe modelirovanie $i$ optimizatsiya ob'ektov khimicheskoy tekhnologii $v$ Mathcad i Excel. Sankt-Peterburg, Rossiaya: SPbGTI (TU).

[39] Kofanov, O.E., \& Kholkovs'kiy, Yu.R. (2017). Geoekologicheskie aspekty modelirovaniya lokal'nogo zagryazneniya prizemnogo at- mosfernogo vozdukha otrabotavshimi gazami avtotransportnykh sredstv. Gornaya Mekhanika i Mashinostroenie, (4), 20-33.

[40] Donchenko, V.V., Kunin, Yu.I., Ruzskiy, A.V., \& Vizhenskiy, V.A. (2014). Metody rascheta vybrosov ot avtotransporta i rezul'taty ikh primeneniya. Zhurnal Avtomobil'nykh Inzhenerov, 3(86), 44-51.

[41] Dem'yanova, V.S., Rodionov, Yu.V., \& Chumakova, O.A. (2013). Otsenka negativnogo vozdeystviya predpriyatiy avtotransportnogo kompleksa na okruzhayushchuyu sredu. Penza, Rossiya: PGUAS.

[42] Karavalakis, G., Poulopoulos, S., \& Zervas, E. (2012). Impact of diesel fuels on the emissions of non-regulated pollutants. Fuel, (102), 85-91. https://doi.org/10.1016/j.fuel.2012.05.030

[43] Vasylkevych, O., Kofanov, O., Kofanova, O., \& Tkachuk, K. (2017). Synergism of stable nitroxyl radicals and amines during the oxidation process of motor fuels and oils at increased temperatures. EasternEuropean Journal of Enterprise Technologies, 6(6(90)), 4-9. https://doi.org/10.15587/1729-4061.2017.118784

[44] Vasylkevych, O., Kofanova, O., Tkachuk, K., \& Kofanov, O. (2016) Alkylphenol derivatives of the polymer of thiocyanic acid and 5amino-1,2,4-dithiazole-3-thione as an effective additives to fuels and lubricants. Eastern-European Journal of Enterprise Technologies, 3(6(81)), 45-50. https://doi.org/10.15587/1729-4061.2016.71267

\section{Зменшення екологічних ризиків від роботи дизельних транспортних} засобів підприсмств гірничодобувної промисловості

\section{О. Кофанов, О. Василькевич, О. Кофанова, О. Зозульов, Ю. Холковський, В. Хрутьба, О. Борисов, О. Бобришов}

Мета. Прогнозування потенційно шкідливого впливу дизельного автотранспорту гірничодобувних підприємств на довкілля й мінімізація спричинених цими впливами екологічних ризиків за допомогою модифікування моторного палива спеціальними присадками та добавками.

Методика. За допомогою методу математичного моделювання, реалізованого у середовищі МаthCAD, оцінено підвищення екологічного впливу на придорожні території та здоров'я людей, спричиненого викидами забруднюючих речовин 3 відпрацьованими газами важких дизельних автотранспортних засобів (АТЗ) підприємств гірничодобувної промисловості. Дані щодо потенційних викидів найбільш небезпечних забруднювачів з відпрацьованими газами АТЗ були узагальнені, як за допомогою власних натурних спостережень, так і за допомогою аналізу літературних джерел. Вплив з боку досліджуваних забруднювачів на довкілля коригували, враховуючи частку важких дизелів, що перевозять вантажі на маятникових маршрутах гірничих підприємств.

Результати. Виявлено підвищення рівня екологічного ризику, спричиненого експлуатацією важких дизельних АТЗ та інших типів дизельної спецтехніки. Запропоновано використовувати метод фізико-хімічного регулювання властивостей моторного палива за допомогою багатофункціональної паливної композиції (присадки), що містить поверхнево-активний та антиоксидантний комплекси. Визначено, що використання розробленої присадки суттєво зменшує навантаження на навколишнє середовище, зокрема, на проїжджу частину - на 26-29\% для оксидів нітрогену і на 39-41\% - для твердих частинок пилу й сажі, тим самим знижуючи екологічний ризик та вплив важкої дизельної техніки на здоров'я людей. Досягнуто суттєве скорочення відстаней, на яких спостерігаються безпечні рівні концентрації досліджуваних забруднювальних речовин.

Наукова новизна. Встановлено, що модифікація дизельного палива розробленою присадкою дає змогу вирішити проблему локального і розсіяного забруднення придорожнього простору, спричиненого викидами важких дизельних АТЗ. Доведено, що використання паливної композиції знижує токсичність відпрацьованих газів дизельних двигунів, скорочує витрату палива, а також покращує умови горіння палива та утворення паливно-повітряної суміші.

Практична значимість. Отримані результати можуть бути використані для підвищення рівня екологічної безпеки придорожніх територій та мінімізації екологічних ризиків, спричинених роботою важких дизельних АТЗ гірничих підприємств, для довкілля та здоров'я людей.

Ключові слова: дизельний автотранспорт, гірничодобувна промисловість, гірничі підприємства, екологічний ризик, присадки, відпрацьовані гази, біодизель

\section{Уменышение экологических рисков от работы дизельных транспортных средств предприятий горнодобывающей промышленности}

\section{А. Кофанов, А. Василькевич, Е. Кофанова, А. Зозулев, Ю. Холковский, В. Хрутьба, А.Борисов, А. Бобрышов}

Цель. Прогнозирование потенциально опасного влияния дизельного автотранспорта горнодобывающих предприятий на окружающую среду и минимизация вызванных этими воздействиями экологических рисков с помощью модифицирования моторного топлива специальными присадками и добавками.

Методика. С помощью метода математического моделирования, реализованного в среде МathCAD, оценено повышение экологического воздействия на придорожные территории и здоровье людей, вызванного выбросами загрязняющих веществ с отработанными газами тяжелых дизельных автотранспортных средств (АТС) предприятий горнодобывающей промышленности. Данные о потенциальных выбросах наиболее опасных загрязнителей с отработавшими газами АТС были обобщены, как с использованием собственных натурных наблюдений, так и с помощью анализа литературных источников. Воздействие со стороны исследуемых загрязнителей на окружающую среду корректировали, учитывая долю тяжелых дизелей, перевозящих грузы на маятниковых маршрутах горных предприятий.

Результаты. Выявлено повышение уровня экологического риска, вызванного эксплуатацией тяжелых дизельных АТС и других типов дизельной спецтехники. Предложено использовать метод физико-химического регулирования свойств моторного топлива с помощью многофункциональной топливной композиции (присадки), содержащей поверхностно-активный и антиоксидантный комплексы. Определено, что использование разработанной присадки существенно уменьшает нагрузку на окружающую среду, в частности, на проезжую часть - на 26-29\% для оксидов азота и на 39-41\% - для твердых частиц пыли и сажи, тем самым снижая 
экологический риск и влияние тяжелой дизельной техники на здоровье людей. Достигнуто существенное сокращение расстояний, на которых наблюдаются безопасные уровни концентрации исследуемых загрязняющих веществ.

Научная новизна. Установлено, что модификация дизельного топлива разработанной присадкой позволяет решить проблему локального и рассеянного загрязнения придорожного пространства, вызванного выбросами тяжелых дизельных АТС. Доказано, что использование топливной композиции снижает токсичность отработавших газов дизельных двигателей, сокращает расход топлива, а также улучшает условия горения топлива и образования топливно-воздушной смеси.

Практическая значимость. Полученные результаты могут быть использованы для повышения уровня экологической безопасности придорожных территорий и минимизации экологических рисков, вызванных работой тяжелых дизельных АТС горных предприятий, для окружающей среды и здоровья людей.

Ключевые слова: дизельный автотранспорт, горнодобывающая промышленность, горные предприятия, экологический риск, присадки, отработанные газы, биодизель

\section{Article info}

Received: 14 November 2019

Accepted: 10 May 2020

Available online: 15 May 2020 